\title{
URAEMIA AND HAEMORRHAGIC COMPLICATIONS OF PHENYLBUTAZONE THERAPY
}

\author{
By J. D. S. Hammond, M.B., M.R.C.P. \\ Research Assistant in Medicine, Medical Professorial Unit, Ryyal Hospital, Sheffield
}

Toxic effects associated with phenylbutazone therapy such as oedema, various types of skin rashes, agranulocytosis, thrombocytopenia, haemorrhagic manifestations and gastro-intestinal disorders are well known. Oedema was considered to be solely due to sodium retention and of little significance until Bruck et al. (1954) first suggested that a toxic effect on the kidney was induced by the drug, and Johnson and Larkin (1954) reported a case where phenylbutazone was considered to have precipitated fatal renal failure.

The present case is reported because the patient recovered in spite of the development of uraemia and multiple haemorrhagic manifestations.

\section{Case Report}

A married woman aged $5 \mathrm{I}$ was admitted to the Rheumatism Research Unit, Sheffield, in August 1954 with a two-year history of arthritis of the hands, wrists, elbows and knees. The diagnosis was thought to be rheumatoid arthritis. Treatment with phenylbutazone, $400 \mathrm{mg}$. daily, was begun and continued under out-patient supervision until March 22, I955, when it was stopped because the patient had developed haemorrhagic skin lesions on both lower limbs. On readmission a week later there was a bullous eruption on both legs from below the knee to the heel, sparing the posterior aspect of the limbs. The bullae were filled with haemorrhagic exudate. There were a few purpuric spots in the intervening skin and pitting oedema of both ankles. No other abnormality was found. The urine was normal, but 12 days later was found to contain albumen. Shortly after this there was vague upper abdominal discomfort and nausea, followed one week later by vomiting on numerous occasions. Backache and tenderness in the right loin occurred, but there were no urinary symptoms. There was an irregular fever rising to a maximum of $99^{\circ} \mathrm{F}$. No further skin lesions had appeared since admission but the bullae had crusted under the influence of penicillin powder. The only other medicinal therapy was calcium aspirin and nembutal.
Five weeks after the onset of the rash there was microscopic haematuria and the urine contained pus cells, a few granular casts and B. coli. The blood urea was I I0 $\mathrm{mg}$. per $100 \mathrm{ml}$. and an intravenous pyelogram showed poor concentration of dye. Treatment of the urinary tract infection was begun with streptomycin, $0.5 \mathrm{~g}$. twice daily, intramuscularly. The patient was transferred to the Royal Hospital under the care of Dr. W. Whitaker.

At this time, seven weeks after the onset of the rash, she was neither seriously ill nor dehydrated, but the presence of haematuria and uraemia was confirmed. There were numerous crusted, healing ulcers on both lower limbs with evidence of previous purpura. The capillary fragility was normal. Examination of the blood revealed no cause for the purpura. The heart and lungs were clinically normal, the blood pressure was $120 / 85$ and an electrocardiogram was normal. There was upper abdominal tenderness but no viscera were palpable. The renal lesion could not be further defined, but phenolsulphonephthalein excretion was greatly impaired; 6 per cent. of the dye was excreted in the first hour after injection and 9 per cent. in the second hour. The urine was, however, sterile and contained no pus cells or casts. X-rays of hands and wrists showed typical changes of rheumatoid arthritis; X-ray of knees showed well-marked hypertrophic arthritis and $\mathrm{X}$-ray of chest and a cholecystogram were normal.

The patient was treated with bed rest, a low protein diet and chlorpromazine, 10s $\mathrm{mg}$. daily in divided doses, in an attempt to control the vomiting. The blood urea continued to rise and the patient became anaemic. There was evidence of occult gastro-intestinal bleeding. Three weeks after transfer the blood urea was $150 \mathrm{mg}$. per 100 $\mathrm{ml}$. and the haemoglobin was $8.9 \mathrm{~g}$. per $100 \mathrm{ml}$. At this time there was evidence of salt depletion (see table). This was considered to be the result of persistent vomiting which now occurred shortly after every meal. She was given $15 \mathrm{~g}$. of salt daily in enteric coated pills and while on this therapy the vomiting ceased and the serum electrolytes re- 
Tabif: Showing Results of Sherial. Iaboratory Invistigations

\begin{tabular}{|c|c|c|c|c|c|c|c|c|}
\hline $\begin{array}{c}\text { Day } \\
\text { after } \\
\text { appear- } \\
\text { ance } \\
\text { of rash }\end{array}$ & $\begin{array}{l}\text { I Iaemo- } \\
\text { globin } \\
\text { g. per } \\
100 \mathrm{ml} \text {. }\end{array}$ & $\begin{array}{l}\text { White } \\
\text { blood } \\
\text { cells } \\
\text { per c.mm. }\end{array}$ & $\begin{array}{l}\text { Platelets } \\
\text { per c.mm. }\end{array}$ & $\begin{array}{l}\text { F.S.R. } \\
\text { mm. in } \\
\text { ' hr. } \\
\text { (Win- } \\
\text { trobe) }\end{array}$ & $\begin{array}{l}\text { Serum } \\
\text { sodium } \\
\text { m.Eq.1. }\end{array}$ & $\begin{array}{l}\text { Plasma } \\
\text { chloride } \\
\text { m.Eq.l. }\end{array}$ & $\begin{array}{l}\text { Blood } \\
\text { urea } \\
\text { mg. per } \\
\text { roo ml. }\end{array}$ & Urine \\
\hline 8 & 12.7 & 7,500 & 325,000 & & & & & Normal \\
\hline 20 & & & & & & & & Albumen + \\
\hline 32 & & & & & & & & $\begin{array}{l}\text { Albumen }+ \text {, red cells }+ \text {, pus } \\
\text { cells }+ \text {, granular casts }+ \text {, } \\
\text { B. coli on culture }\end{array}$ \\
\hline $4 \mathrm{I}$ & 12.6 & 10,300 & & & & & I IO & $\begin{array}{l}\text { Albumen }+, \text { red cells }+, \text { pus } \\
\text { cells }+ \text { granular casts }+\end{array}$ \\
\hline 50 & I 32 & 10,000 & 357,000 & 62 & I 33 & 90 & 9 I & Albumin + , red cells + , sterile \\
\hline 67 & 99 & 10,000 & & 62 & I 31 & 90 & I 18 & $\begin{array}{l}\text { Albumen }+ \text {, red cells }+ \text {, granu- } \\
\quad \text { lar casts }+ \text {, sterile }\end{array}$ \\
\hline 73 & 89 & 12,000 & 337,000 & $6 I$ & I 23 & 84 & I 50 & Albumen,+ red cells + , granu- \\
\hline 80 & 102 & & & & 138 & 93 & $5^{6}$ & $\begin{array}{l}\text { Albumen }+ \text {, red cells }+ \text {, granu- } \\
\text { lar casts }+\end{array}$ \\
\hline 94 & I 29 & 9,000 & $315, \infty 00$ & $6 j$ & I 34 & 94 & 30 & Albumen + , red cells + , sterile \\
\hline 104 & I $3 \cdot 2$ & 8,000 & & 52 & 134 & $9 j$ & 31 & $\begin{array}{l}\text { Albumen }+ \text {, red cells }+ \text {, granu- } \\
\text { lar casts }+ \text {, sterile }\end{array}$ \\
\hline
\end{tabular}

Notes: The phenylbutazone was stopped on the first day.

Urine: + signifies present.

Negative findings not indicated except in the case of culture.

turned to their original values. After five weeks there was considerable improvement in the general condition of the patient and she was allowed up. Four days later a new crop of haemorrhagic bullae appeared on both lower limbs, grouped as before laterally, medially and anteriorly above the ankles. A biopsy was now taken of one of these lesions and was reported on as follows: "The corium shows granulation tissue with considerable formation of young fibrous tissue. Between the fibres are extravasations of red cells; haemosiderin is present in macrophages. There is atrophy of the overlying epidermis.'

Improvement, however, continued; the blood urea fell progressively to normal levels and the haemoglobin rose to $13.2 \mathrm{~g}$. per $100 \mathrm{ml}$. after transfusion with 2 pt. of packed cells. Before discharge the renal function had been retested; 22 per cent. of the phenolsulphonephthalein was excreted in the first hour after injection and 12 per cent. in the second hour. Faecal occult blood tests had been persistently positive during the patient's admission, but no lesion was found on barium meal examination.

When the patient was finally discharged from hospital on July I6, I955, she was symptom free, apart from the disability resulting from her arthritis, and clinical examination revealed a healing skin eruption and the arthritis as the only abnormalities. Urine showed a cloud of albumen; the wet film showed a few red blood cells, an occasional granular cast but no pus cells; culture was sterile. A urine concentration and dilution test showed a specific gravity range of from 1,004 to I,OIO. An important negative finding in this case was that she never became clinically jaundiced and the serum bilirubin was always normal. The urine never contained urobilin or bile and the plasma proteins were normal.

\section{Discussion}

In a review of the toxic effects of phenylbutazone, Bruck et al. (1954) found that the majority occurred in the second and third weeks of therapy, though in an occasional case complications developed up to six months after starting therapy. The present case is unusual in that toxic effects developed seven months after treatment was commenced.

When the skin rash appeared the drug was stopped and albuminuria, which was the first indication of renal damage, was not noted until 20 days after cessation of therapy. However, since Bruck et al. (1954) found that excretion persisted for 10 to 20 days after stopping phenylbutazone, and Pemberton (1954) was able to detect appreciable blood levels two weeks after discontinuation of therapy, it is reasonable to assume that the drug was still present in this patient and exerting a toxic effect on the kidney up to the time when albuminuria was discovered.

Haematuria, albuminuria and uraemia have been previously described as complications of phenylbutazone therapy. Stephens et al. (1952) reported two cases with gross haematuria without thrombocytopenia; the bleeding ceased when the 
drug was stopped. Benstead (1953) reported a patient with pain in the loin and haematuria who died within 24 hours and was found at autopsy to have an unsuspected perforated duodenal ulcer and coarsely scarred kidneys. Bowers (1953) reported a male gouty patient who died with complete anuria following haematuria. Death was attributed to the precipitation of uric acid or one of its salts in the urinary tract caused by phenylbutazone. A fatal case, with a normal blood urea, in which the urine had contained albumen, a few red blood cells and granular casts and in which the autopsy examination revealed widespread vascular lesions in the kidneys and other organs was described by O'Brien and Storey (1954). They attributed these lesions to a state of hypersensitivity to phenylbutazone. Peebles Brown and Currie (I952) reported two cases with slight transient albuminuria which disappeared although the drug was not stopped. Renal and hepatic necrosis have been recorded recently in a fatal case described by MacCarthy and Jackson (1955). In this case the urine contained albumen, the blood urea was not recorded and at autopsy the glomeruli were normal but there were widespread degenerative changes in the tubules. Contracted kidneys were present in a fatal case which was found at post-mortem examination to have multiple superficial gastric ulcers (British Medical fournal, 1952). Bruck et al. (1954) reported a fatal case of uraemia where the kidneys were small and granular and showed evidence of past pyelonephritis and hypertension. Johnson and Larkin (1954) reported another fatal case with small, contracted kidneys.

All six reported cases with renal complications of phenylbutazone therapy, other than simple haematuria and slight transient albuminuria, have died and in three of these cases (Benstead, 1953; Bruck et al., 1954; Johnson and Larkin, 1954), two of whom became uraemic, there was autopsy evidence of previous chronic renal disease. In Bowers' case (1953) anuria was attributed to either water retention or massive excretion of uric acid as a result of phenylbutazone. In the case described by O'Brien and Storey (1954) the blood urea was normal prior to death and the level was not recorded in the one reported by MacCarthy and Jackson (1955); albuminuria, however, was only present for three days before death took place.

The present case appears to be the first in which uraemia developed as a complication of phenylbutazone therapy where there was no evidence of previous associated chronic renal disease and in which the outcome was not fatal. The mild, short-lived urinary tract infection could hardly explain the prolonged period of uraemia or the persistently abnormal urinary findings long after it was eradicated. The salt depletion probably contributed to the further rise in the blood urea, but did not appear until well after uraemia had developed. The presence of haemorrhagic manifestations lends strong support to the hypothesis that a toxic effect from the phenylbutazone was responsible. The possibility of a vascular reaction such as lupus erythematosus was considered, but no support was found for this by tests for the presence of L.E. cells in the peripheral blood or bone marrow.

The fall in blood urea to a normal level and the improvement in renal function suggested that the phenylbutazone had caused a reversible lesion in the kidney, possibly similar in nature to that described by O'Brien and Storey (1954). The persistent albuminuria and microscopic haematuria at the time of discharge indicates that renal damage is still present and the inability of the kidney to produce a concentrated urine, in the presence of a normal blood urea, suggests predominant impairment of tubular function. This is in keeping with the findings of tubular changes in the fatal cases described by Bruck et al. (1954) and MacCarthy and Jackson (I955).

That uraemia developed in a patient with no evidence of previous renal damage and in whom the condition proved reversible only after a prolonged illness, adds strong support to the suggestion of Johnson and Larkin (I954), that poor renal function might prove to be an important contra-indication to the use of phenylbutazone.

\section{Summary}

A case is reported in which multiple toxic effects occurred in a patient who was receiving phenylbutazone for rheumatoid arthritis. There was involvement of skin, gastro-intestinal tract and kidneys with fluid retention and marked uraemia, from which the patient recovered.

Previously reported cases with renal complications of phenylbutazone therapy are reviewed and the present case compared with them.

I wish to thank Dr. W. Whitaker for permission to publish the case and both Dr. Whitaker and Professor C. H. Stuart-Harris for helpful criticism and advice.

\section{BIBLIOGRAPHY}

BENSTEAD, J. G. (1953), Brit. med. F., i, 711 .

BOWERS, V. H. (1953), Ibid., i, 617 .

BRITISH MEDICAL JOURNAL, 1952, ii, 1427.

BRUCK, E., FEARNLEY, M. E., MEANOCK, I. and PATLEY, H. (1954), Lancet, i, 225.

JOHNSON, B. MCD. and LARKIN, I. M. (1954), Brit. med. F., ii, 1088.

MacCARTHY, J. M. and JACKSON, R. T. (1955), Ibid., if, 240. O'BRIEN, D. J. and STOREY, G. (1954), Ibid., i, 792.

PEEBLES BROWN, R. A. and CURRIE, J. P. (1952), Lancet, ii, 682 .

PEMBERTON, M. (1954), Brit. med. F., i, 490.

STEPHENS, C. A. L., YEOMAN, E. E, HOLBROOK, W. P. HILL, D. F. and GOODWIN, W. L. (r952), $\mathscr{f}$. Amer. med. Ass., 150, 1084. 